'All Men Are Created Equal': Walker, Delany and the African Colonisation Bigotry 


\title{
RELIGION AND PHILOSOPHY
}

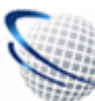

UAS
LWATI: A Journal of Contemporary Research, 7(4), 317-330, 2010

ISSN: $1813-2227$

\section{'All Men Are Created Equal': Walker, Delany and the African Colonisation Bigotry}

\author{
Michael Andindilile \\ Department of Literature, University of Dar Es Salaam \\ Dar Es Salaam - Tanzania \\ Email: Mandindilile@Hotmail.Com
}

\begin{abstract}
This essay examines two historical documents-David Walker's Appeal to the Coloured Citizens of the World and Martin R. Delany's The Condition, Elevation, and Destiny of the Colored People published in 1929 and 1952, respectively-to stress the rhetorical astuteness of African-Americans writing from the margins in hostile antebellum America. The essay argues that, rhetorically these documents expose America's weaknesses and contradictions between the principles of freedom that motivated the country's founding fathers and the compromises that recognised and permitted the continuation of slavery. Specifically, these rhetoricians exploit and subvert Thomas Jefferson's paradoxical, if not conflicting, thesis on the status of African-Americans in America to advance their argument.

We hold these truths to be self-evident, that all men are created equal, that they are endowed by their Creator with certain unalienable Rights that among these are Life, Liberty, and the Pursuit of Happiness.
\end{abstract}

-Thomas Jefferson (1776)

\section{INTRODUCTION}

Thomas Jefferson, one of America's founding fathers, penned these wordsnow the pillar of the US Constitution - at a time when he ironically owned about 200 slaves, none of whom he set free even upon his death. Jefferson thus never meant these words to apply to black people in America, the majority of whom were then treated as nothing more than property in that society. Jefferson also suggested in the eighteenth century that African colonisation was the solution to the Negro problem in the US since blacks, whom he perceived as "inferior to the whites in the endowments of body and mind," posed a threat to the American way of life (Staudenraus 1961: 1, 2). 
This argument became a guiding principle of the American Colonisation Society formed in 1817 to implement the back-to-Africa scheme for free or manumitted blacks. Jefferson thus epitomises the paradoxes of the United States: on the one hand he advocates freedom for "all men" and on the other a racist ideology for blacks. He symbolises the ambivalence inherent in American values that anti-slavery and anti-colonisation rhetoricians pounced on to agitate for the rights of blacks within the US.

\section{David Walker and Martin Delany ${ }^{1}$}

David Walker and Martin Delany are two African-American rhetoricians who exploited this ambivalence to build a case for blacks in America. Though Walker and Delany have attracted much scholarly interest, rarely are their documents-the Appeal and The Condition-examined together, let alone examined for their rhetorical strategy in undermining the premises of the African Colonisation Movement. As Brown (1979: 251) points out, much research has focused on "the role of the free blacks in the African Colonization Movement" but "few scholars have focused on the rhetorical impact of the free blacks on African Colonization through the spatial evolvement of discourse and the emergence of key rhetorical exigencies”. In this essay, I close-read Walker's and Delany's documents to examine their rhetorical strategy in undermining the core arguments of the African Colonisation Movement by embracing and subverting the Jeffersonian thesis. The goal of the essay is to use Walker and Delany to underscore the role of African-Americans in the anti-slavery and anti-colonisation movement often "diminished or obscured by European scholars" whereby "people of African descent are relegated to a peripheral status" (Forbes 1990: 210). The essay focuses on the rhetoric of Walker and Delany to determine how the two documents "exposed [America's] weaknesses" and "heighten[ed] the many contradictions between the principles of freedom that motivated the Founding fathers and the compromises that recognised and permitted the continuation of slavery" (Blackett, 386).

Walker belongs to the first wave (the 1829-1834 period Rosen [1972] calls "the years of conflict") of anti-colonisation advocates, when the American Colonisation Society was at the height of its power; Delany belongs to the post-1950 second wave, when the floundering Society was trying to resurrect the wavering public support amidst increasing desperation for AfricanAmericans. Walker and Delany unite in the Appeal and The Condition, respectively, in subverting and reformulating the Jeffersonian thesis on African-Americans to undermine popular sentiments on blacks. The Appeal and The Condition are structured first, to reposition African-Americans as part of "all men" and second, to dismiss as irrelevant any white-engineered moves to repatriate them to Africa. Both rhetoricians succeed to highlight the human aspect of African-Americans (to which mainstream America would 
rather turn a blind eye) to reassert the place of the African-American in the US. The strategy was first, to destroy the myth of the inferiority of the African-American; second, to insist that liberty and the elevation of AfricanAmericans were inseparable. I argue that Walker's and Delany's rhetoric emphasises the same American values of life, liberty and pursuit of happiness (that Jefferson's famous phrase highlights) denied to blacks in order to undermine the anti-black and pro-African colonisation argument of the American Colonisation Society. ${ }^{2}$

True to the Jeffersonian thesis, the Society's main argument was that in America, "public opinion does, and will consign [the African American] to an inferiority, above which he can never rise" (ACS 1832: 14). Many of the pro-colonisation advocates took Jefferson's tentative thesis on the supposed inferiority and incapability of Africans as gospel truth. This misconception was sustained despite Jefferson's acknowledgement of the unscientific nature of his discovery. Jefferson (1904) does make it clear in "Notes on the State of Virginia", though, that this is merely a tentative theory since he uses the words, "I advance it... as a suspicion only." Later in a letter to a gifted free African-American Benjamin Banneker, born to an English woman and a former African slave, he admits that "the lack of talents observed" among African-Americans was "merely the effect of the degraded condition, and not proceeding from any difference in the structure of parts on which intellect depends." To the Society in its nefarious drive, the dubious nature of their core argument did not matter. The Society insisted it would ship them to Africa "the land of their fathers" ${ }^{3}$ with their "consent" despite fierce opposition from free African-Americans.

Both Walker and Delany expose the hypocrisy of the Society by highlighting the ideals of freedom that Jefferson so clearly expressed to advance their argument on the one hand, and undermining his racist claims on the supposed inferiority of blacks, on the other. For example, Walker (2000: 30) asserts,

For my part, I am glad Mr. Jefferson has advanced his positions for your sake; for you will either have to contradict or confirm him by your own actions, and not by what our friends have said or done for us; for those things are other men's labours, and do not satisfy Americans, who are waiting for us to prove to them ourselves, that we are MEN, before they will be willing to admit the fact.

Walker deliberately reserves this portion of a statement he starts making in Article I where he identifies ignorance of their potential as the bane amongst African-Americans.

\footnotetext{
${ }^{2}$ Any subsequent reference to "Society" with initial capital letter refers to the American Colonization Society

${ }^{3}$ This was a famous phrase among African colonisationists, which recurs in many of the speeches P.J. Staudenraus quotes in The African Colonization Movement 1816-1865 (New York: Columbia University Press, 1961)
} 
Delany also builds his argument around Jefferson's ideals of freedom and the implications of his racist statements. Delany (1962: 154), seeing the effects of the Fugitive Slave Law, realised the full extent of the hypocrisy of the American system that proclaimed "all men are created equal", on the one hand, and enacted a new law that legally acknowledged the "inferiority of birth" of African-Americans, on the other. With this law, the black man was "degraded below the level of the whites" and would have to be hunted and re-enslaved without the allusion of "habeas corpus, or a fair trial" because the bill does not provide for this. If anything, they had to rely on "the whims or caprice of the magistrate" (ibid: 154, 155). Hence "our rights and liberty" were "entirely at [the whiteman's] disposal.” Delany's statements were also being made against the backdrop of renewed attempts by the African Colonisation Society to repatriate more blacks to Africa.

Following the success of Britain in establishing a British colony for the resettlement of freed Blacks in Sierra Leone, people like Robert Finley, a Presbyterian minister, saw this as a template for solving the Negro problem in the US. As a practical solution to the Negro question, however, "colonization was a failure from the beginning. Yet many powerful, influential, and intelligent national leaders sincerely believed that colonization was the answer to the problem" (McPherson 1965: 398). In 1816, fifty leading white, primarily Southern, slaveholders and sympathisers, including prominent clergymen and politicians, came together to form this movement. These included Judge Bushrod Washington (a nephew of George Washington), Francis Scott Key (the author of the Star Spangled Banner), and General Andrew Jackson (who later became a US president). Abraham Lincoln and Thomas Jefferson were also supporters of the society. These historical figures in American lore illustrate the kind of tide black rhetoricians faced to counter aggressive white anti-black ideology and procolonisation rhetoric.

By the late 1820s, when the Appeal came out, the "key writings of Jefferson only sanctioned this mounting racism" and Walker produced the Appeal to help African-Americans "refute this nefarious doctrine", "the ideological centerpiece of American racism" (Hinks 2000:xxvii) since "the pervasive indictment of black character spawned by Jefferson's words might profoundly demoralize African Americans" (ibid: xxvii, xxx). Thus there was a need for blacks to raise awareness amongst African-Americans in the light of heightened white pro-colonisation propaganda. The first AfricanAmerican newspaper, the Freedom's Journal, started in 1827 by John Russwurm and Samuel Cornish, was aimed at changing public opinion mostly amongst blacks. The editors of this anti-colonisationist publication declared, "We wish to plead our cause. Too long have others spoken for us. Too long has the publick been deceived by misrepresentations" (Swift 1973: 439).

Walker's Appeal went even further, by not only targeting black readers, but also exploiting indirect discourse to undermine popular opinion of mainstream white American. Walker's Appeal poses a different challenge to 
antebellum America. As Forbes (1990: 213) notes, the "power of the press was nowhere more evident than in the publication of David Walker's Appeal to the Coloured Citizens of the World". This pamphlet is also "the single event...[which] triggered the Negro revolt" (Walker 1829: vii). Recent historians strongly believe that Walker's Appeal played a key role in inciting Nat Turner's1831 slave revolt, the most dreaded in the US history. The rhetorical power of the Appeal also ushered in the transition from gentle persuasion to militant crusading for African rights. Though some of the white liberals, including Garrison, did challenge Jefferson's claims, Walker strategically refers to that as "other men's labor" because "we, and the world" would like "Mr Jefferson's charges refuted by the blacks themselves" (p.17). The insistence on the blacks speaking for themselves raises the issue of self-awareness and pride.

Instead of appealing to white American for sympathy, as white abolitionists and anti-colonisationists such as William Lloyd Garrison did, Walker appeals to African-Americans themselves to prove to the world that they do not deserve the treatment they get from white America. Through an impassioned language, Walker tries to wrest the initiative of life and liberty from sympathetic whites into the hands of the blacks. He urges his fellow AfricanAmericans to be in control of their destiny instead of relying solely on the goodwill of whites. His strategy of directly addressing African-Americans is aimed at "awaken[ing] in the breasts of my afflicted, degraded and slumbering brethren, a spirit of inquiry and investigation respecting our miseries and wretchedness in the Republican Land of Liberty" (Walker 1829: 5). The emphasis on "Republican Land of Liberty" brings to the surface contradictions in American values.

Often overlooked is Walker's astuteness in formulating and structuring the Appeal. The positioning the subject of anti-colonisation in the last section of this pamphlet shows that Walker wanted his Appeal to be more than just an anti-colonisation pamphlet. For Walker, colonisation was only part of the problem, not the fundamental issue. Walker wanted the issues of liberty to be addressed first to improve the welfare of the coloured people within the US. The Appeal prioritises ideas that would help African-Americans understand the basic issues regarding slavery so that they would not be cowed into accepting being uprooted from the US, hence the statement: "this country is as much ours as it is the whites', whether they will admit it now or not, they will see it by and by." With such a stand, Walker goes on to show why the Africans have to take the initiative and fight for their rights.

Having lived in Boston and travelled around Southern states, Walker knew that without standing up for their rights, African-Americans would perpetually be at the mercy of whites, and eventually be forced out of the country. Not surprisingly, in Article I (of the four-articled) Appeal, Walker addresses slavery as the cause of their "wretchedness", before moving on to ignorance, then to the preachers of religion, and finally African Colonisation in Article IV. There is a pattern of cause-effect emerging in this arrangement. One cannot undermine the African colonisation argument without addressing 
the issue of slavery. To keep slavery in check, those perpetrating it must ensure the enslaved remain in ignorance because as soon as the slaves realise their potential collective power, they would break from the chains of bondage. Walker also exposes the hypocrisy of religion in America and how it was used to suppress African-Americans.

Walker begins his Appeal in an uncharacteristic manner, with an admission, which many African-Americans would find hard to make, that "We, (colored people of these United States,) are the most degraded, wretched, and abject set of beings that ever lived since the world began" (p.3). This is the reality and the level at which African-Americans were held at that time. With this declaration, he forces his audience to admit the fact, a necessary step for someone who ought to make amends. To set the framework of his discussion, Walker also draws comparisons with other peoples in the world who have been enslaved in the past. His point is that, unlike other races, only the African cannot be called a man. The comparison he draws between the treatment of slaves in "heathen nations" and in "Christian America" helps Walker to set his rhetorical agenda. Without stating directly, he casts Christian slaveholders in America as worse than heathens in Rome, or Egypt. Walker notes that African-Americans would "go on enriching [whites], from one generation and another with our blood and our tears!!!”(p.9) if they remained docile. Walker's Appeal thus seeks to make African-Americans realise their worth as human beings and re-discover their noble history in Africa. This is the primary objective of the Appeal.

Much has been made out Walker's "Kill or be killed" statement in the Appeal because of the brutal reality is evokes, but this statement does not constitute Walker's primary objective. Walker makes this statement against the backdrop of actions of African-Americans that did nothing to prove the antiblack ideology wrong. For example, Walker asks, "How can [whites consider them as men] when we are confirming [Jefferson's thesis] every day, by our groveling submissions and treachery?” Before making this statement, Walker has prepared the readers by letting them read an article titled "Affray and Murder" in which victorious Negro slaves, who after killing a couple of their oppressors are betrayed by another slave. This treachery, Walker points out, is a result of three centuries in which whites have been "murdering, and treating us like brutes" (p.27). As a result, mainly because of ignorance, many of the blacks were resigned to their fate. Then Walker wakes them to a new reality, that if "an attempt is made by us, kill or be killed"(p.28). Hence, isolating this statement ignores the broader agenda of Walker's rhetoric.

As Article II illustrates, Walker knows that ignorance and treachery are counterproductive forces for African-Americans. Like in Article I, Walker explores the historical fact that the African was always ignorant, or predisposed for "groveling servile and abject submission" as the white Americans would rather make them believe (p.23). By tracing African knowledge to a distant past, Walker rebuts the myth that Africans have always been ignorant. But even in that historical past, he cites disunity as a stumbling block. The challenge is for the "brethren" to "go to work and 
enlighten your brethren” (p.32). However, Walker knows that education is not just learning to write. Education should be able to be translated into knowledge, knowledge that will help liberate them. Walker insists that the whites denied African-Americans education because if "the coloured people were to acquire to acquire learning in this country in this country," then "their infernal deeds of cruelty would be known to the world" (p.34). Having established that it would be impossible to liberate themselves while they were ignorant of their state, potential to rise and confound critics, Walker turns his attention to American preachers.

Characteristically, Walker begins this section with an historical fact, asserting how a "pretended preacher of the gospel of Jesus Christ" led to the importation of the first African slaves to Africa. Walker uses this link to the birth of slavery in America to foreground a hypocritical version of religion practiced in America, which allows thousands to beat up "coloured person nearly to death, if they catch him on his knees, supplicating to the throne of death"(39). Moreover, Walker exposes how religion in America has been hijacked to justify slavery. He believes the preachers have a duty to "preach against ...oppression and to do their utmost to erase it from the country," and yet they choose complicit in slavery, so that when others observe them they can say, "our preachers, who must be right" "treat them like brutes... why cannot we?” (p.40). Walker makes his audience realise that the bible makes no distinction of colour the "pretended preachers" in the US highlighted. By exposing the hypocrisy inherent in the American version of Christianity, Walker dismisses the myth that whites were ordained by God to be masters over blacks. Clearly, Walker wants Christianity to condemn, not sanction slavery.

By the time, Walker tackles the issue of African colonisation he has prepared the reader to be dismissive of the back-to-Africa call. By then, Walker has established the framework within which the colonisationists advocate the return of African-Americans to Africa argument:

Let no man of us budge one step, and let slave-holders come to beat us out from our country. America is more our country, than it is the whites-we have enriched it with our blood and tears. The greatest riches in all America have risen from our blood and tears:-and will they drive us from our property and homes, which we have earned with our blood? (p.67)

Walker stresses that blacks have earned their right to live in America with their sacrifice and industry.

In this fourth and final article, Walker starts by dissecting Henry Clay's speech, pointing out anomalies in his statements. On the Society's purported attempt to make a part of Africa "instrumental to the introduction into that extensive quarter of the globe, of the arts, civilization, and Christianity", Walker asks whether it is the same kind they have in America in which they ruled with "whip, blood and oppression" (p.48). Walker exposes Clay for declaring that they were "innocent of the blood and groans of their fathers" (p.48) and for excluding the issue of slavery from the agenda of the Society. Clay, the society's president, argued, the society had to preclude the 
"question of emancipation" or "abolition of slavery" altogether to win the | support of the South and the West (Rosen 1972: 191). This omission prompted the majority of free African-Americans to suspect the real motives of the Society and thus, as Moses (1978: 34) notes, they "came to think of the American Colonization Society as a wolf in sheep's skin". As a result, the National Negro Convention Movement strongly opposed the Society and dissociated itself from its aims. Walker projects the Society's initiative as a plan "to get those of the coloured people, who are said to be free, away from those of our brethren whom they unjustly hold in bondage, so that they may be enabled them more secure in ignorance and wretchedness... and ultimately they would have more obedient slaves"(49). Walker uses the phrase those "said to be free" because he knows, in reality, they are not free. Walker's rhetorical strategy is to expose the hypocrisy inherent even in the most subtle statements.

As part of his strategy, Walker publishes a letter in full of Bishop Richard Allen of the African Methodist Episcopal Church, who in the Freedom's Journal questioned the logic behind sending an "unlettered people, brought up in ignorance, not one in a hundred can read or write, not one in a thousand has liberal education" to a far away country "among heathens, to convert and civilize them" (p.59). Walker includes this letter because it expresses the reality of the situation in addition to exposing the hypocrisy of the Society and its mission. As the clergyman points out, of what good would a man without a solid educational base be in a civilising mission since the Southern slave-holders believe that the "more ignorant they can bring up the Africans, the better slaves they make” (p.59). Moreover, the letter questions why only the free should be sent away. Thus, when he asks his audience to choose amongst "those great men," between Clay and his slaveholding party, and Reverend Bishop Allen, and his party, "men who have the fear God, and the welfare of their brethren at heart", certainly Walker has made a choice for his readers.

Considering the time when the book was written and its overall message, Delany's The Condition can-to a certain extent-be seen as a further development of Walker's Appeal. Like Walker-despite any argument to the contrary—Delany also strongly believes black elevation must first and foremost be pursued within the US. The Condition, paradoxically, captures Delany's emigrationist views in the early 1850 s as well as his fierce opposition to colonisation. It is in this regard that Wallace (1997) speculates that, "anticipating a rejection, Delany composed the first drafts of The Condition, Elevation, and Emigration while awaiting word on his invention from Washington". Delany's book of political analysis, which is grounded in theories of nationality and citizenship, bemoans the fate of AfricanAmericans in America. The "conflicting sense of possibility and disillusionment," as Levine (1997) puts it, "informs and complicates the emigrationist politics of the book." At that time, he had just been expelled from the Harvard Medical School for being black, and the state had just passed the Fugitive Slave Law, and he was seriously considering colonising 
some areas in Central and South America. The problem was that his objection to colonisation was accompanied by his embracement of voluntary black emigration. As a result, scholars such as Forbes (1990: 220) have classified Delany as "one of the best-known Black endorsers of antebellum African colonization". But these scholars tend to confuse Delany's support for black-engineered voluntary emigration with the white-engineered African colonisation. Thus Forbes errs when asserts that in the late 1840s, Delany proposed "colonization" (which should read emigration) "as a solution to slavery and the institutional racism and discrimination characterizing American society” (ibid.). It is evident that Delany' The Condition has been misunderstood.

In this document, Delany cautions the black community about two techniques of elevation that cannot succeed. The first one is the call for colonisation, which makes it clear that he is anti-colonisation. His denunciation of colonisation distinguishes between colonisation and emigration. Critics of separatism in general, and critics of Delany in particular, see no distinction and condemn him as pro-colonisation. But Delany makes the distinction clear in his definition of colonisation:

When we speak of colonization, we wish distinctly to be understood, as speaking of the 'American Colonization Society' —or that which is under its influence of Mr. Henry Clay of Ky., Judge Bushrod Washington of Va., and other Southern slaveholders, having for their object, as their speeches and doings all justify us in asserting in good faith, the removal of the free colored people from the land of their birth, for the security of the slaves, as property of the slave propagandists. (p. 30)

Delany sees colonisation as a white-initiated movement to forcibly remove free blacks from the United States to protect the institution of slavery. On the other hand, Delany considers emigration, as a black-initiated, voluntary movement that takes 'the destruction of slavery as one of its important aims" (Khan 1984: 418). One can even push the argument further and note that emigration was Delany's alternative to Walker's controversial "Kill or be killed". It is also worth noting that the circumstances that prevailed in the early 1950s might have forced Delany's hand. Overall, Delany does not preclude the prospect of African-Americans fighting for their rights within the US.

Delany's rhetorical strategy was to first give the public facts about AfricanAmericans in a bid to tilt public opinion in their favour. In this aspect, his approach is similar to Walker's, if not much more elaborate. Delany (1852: 7) set to "place before the public...and the colored people of the United States...great truths" concerning African-Americans, which appeared to "have been heretofore avoided" by both "friends and enemies to their elevation". Delany (1852: 8) points out that the "colored people of today are not the colored people of a quarter century ago, and require different means and measures to satisfy their wants and demands, and to effect their advancement". He also points out that no American statesman will adopt with the satisfaction of the American people now the same measures 
implemented twenty-five year ago. Incidentally, Delany refers to the same period when the Society was formed. The implication is that the Society's scheme was out of date. ${ }^{1}$

Delany's argument is that white abolitionists and colonisationists have for many years "presumed to think for, dictate to, and know know better what suited colored people.” In this particular respect, he shares a lot with Walker who also stresses the same point. As a result, everything Americans knew about African-Americans came from the white man. On this aspect, Shelby (2003: 670) aptly observes that Delany is "particularly dismayed when blacks allow whites, even those sympathetic to black interests, to think for them, and thus he consistently urges blacks to resist white paternalism". This is evident on pages 10, 25-30,170-71, 190-91 of The Condition where Delany consistently urges African-Americans to restore their racial pride by speaking for themselves. Delany strongly believed that all projects for the elevation of the Negroes should originate with them and be implemented by them. Though The Conditions was not well-received by most of the AfricanAmericans at the time of publication, the document struck a note of racial pride in black America. It is the same racial pride that Walker seeks to instil amongst African-Americans in his Appeal. The opponents of Delany dismiss him for mentioning "emigration", often overlooking his strong argument for the African-American's right to staying in the US. Moreover, his "emigration" call on the black man's terms was supposed to be considered as one of the alternatives, not the only option. It is in this way that Delany could advocate emigration and fiercely oppose the African Colonisation Movement at the same time.

Khan (1984), Wallace (1997) and Shelby (2003) have tried to justify Delany's "separatist ideology". But perhaps Delany's best defence can be found in the focus and emphasis of The Condition and the placement of the voluntary black emigration argument at the very end of the book. In the analysis of Delany's Condition, what is often taken for granted is the way Delany constructs his argument, for this sheds light on the primary emphasis of the book. Before arguing for the African-American's right to American citizenship, Delany dismisses the Society as "as one of the most arrant enemies of the colored man" (p.31). He accuses the Society of harbouring malicious intentions on the black man, "ever seeking to discomfit" a black man and "envying him of the privilege that he may enjoy" within the United States. Delany argues that the Society's actions have no "justification other than being malicious" (p.31). Acknowledging that there were good white people who may favour colonisation, on the one hand, Delany derides the Society for its suspicious intentions on the other. For Delany, a society whose "very origin...being the offspring of slavery....is sufficient to blast it in the estimation of every colored person...who has sufficient intelligence to comprehend it” (p.35). In other words, a black man can only accede to the demands of the Society if he is ignorant of the facts about the Society. Here one notes parallels with Walker, who also identities ignorance as the cause of the African-American's wretchedness. 


\section{Michael Andindilile}

To back up his demands, Delany goes to enormous lengths to establish the right of the African-American to American citizenship, dedicating a chapter to proclaiming the basis of that citizenship and another to grounding that claim in historical facts. He states categorically, "We are Americans, having a birthright citizenship-natural claims upon the country—claims common to all our fellow citizens" (p.49). With this statement he leaves no doubt that there is no need to consider the African-American as an alien in his own nation. The use of "birthright" and "natural rights" deliberately counters any exclusion on the basis of laws enacted by the white man. Delany spats in the face of the Society when he declares: "Here we are born, here raised and educated....and from here will we not be driven by any policy that may be schemed against us" (p.48). Here one notes the same emphasis that Walker makes in his Appeal. It is such statements that those who accuse Delany of being pro-colonisation tend to ignore. In fact, Delany justifies this right in the subsequent chapter, "Claims of Colored Men as Citizens of the United States", in which he shows how the "forests gave way before them, and extensive verdant fields, richly clothed with produce, rose up as magic before these hardy soils" (p.66) in the South, and how they helped to build towns in the North. Furthermore, in another chapter, "Colored American Warriors", Delany depicts the African-American as a revolutionary who helped to "fight battles" for the independence of the US from Britain, which he calls "the highest claims an inhabitant has upon his country" (p.67). With a flurry of accounts, he highlights the gallant roles played by African-Americans in the cause of the nation and, hence, earning his right to citizenship:

The deed of these tried and faithful daring sons of Liberty, and defenders of the country, shall live triumphantly, long after the nation shall have repented her wrongs towards them and their descendants, and hung her head with shame, before the gaze of manhood's rebuke (p.85).

Here Delany attempts to re-write history and let Americans see the oftenignored facts about the Revolution. Also the allusion to the facts that white historians generally tend to ignore is obvious. Delany talks of "faithful daring sons of Liberty" in reference to African-American heroes to allude to the American founding fathers who also cherished liberty, and then hints at the betrayal of African-Americans despite their sacrifice to the cause of their nation. By entrenching his argument in history, carefully chosen as the evidence is, Delany wants to dismiss any attempt to supplant the AfricanAmerican from his native land in which he has earned a right to live.

Like Walker's Appeal, Delany's Condition was not only written to counter the spirit of the Society since even from its outset the African-Americans were strongly opposed to its cause. The agenda apparently, like Walker's, is to instil black pride in African-Americans to empower them. Delany explores "the mode and means of our elevation within the United States" (p.36). By discussing the ways in which African-Americans can improve their welfare within the United States, Delany echoes voices of African-Americans, both past and present, opposed to the objectives of the Society. He wants AfricanAmericans to attain positions in society in order to stop allowing "their 
mothers, sisters, wives and daughters, to do the drudgery and menial offices of other men's wives and daughters" (p.43). Otherwise, it would be "useless...nonsense...pitiable mockery, to talk about equality and elevation in society" (p.43). While acknowledging the plight of the African-American, he does not want them to wallow in self-pity. He wants them to rise above the "position in which we are now prostrated" because fate is in their hands: "Our elevation must be the result of self-efforts, and work of our own hands" (p.46). This, too, has echoes of Walker's Appeal, which also stresses the same point.

As a matter of encouragement, Delany produces evidence to substantiate progress among African-Americans despite the odds stacked against them. The purpose is to show "the attainments of colored men and women", whothroughout their existence in America- "have been "citizen members of community" (pp.85, 92). His evidence covers both pioneering AfricanAmericans and contemporaries who have exerted their talent. He produces a list of professional men of colour who have made it within America despite the obstacles stacked against them. The strategy of illustrating how progressive the black man can be despite being treated as second-class citizens has a dual purpose: first it encourages African-Americans to rise to the occasion and improve their lot; second it undermines misconceptions that a person of colour cannot excel in the US, and thus undermine the Society's cardinal principle plucked from the Jeffersonian thesis.

Like Walker's declaration "Kill or be killed", Delany's black voluntary emigration should be perceived within the framework of the period he was writing in and the position where he places this issue in relation to everything else he says earlier. Coming as the section does after a chapter on "National Disenfranchisement of Colored People,” Delany explores other alternatives while juggling with self-elevation within the United States. The Fugitive Slave Law apparently made Delany see the full extent of the hypocrisy of the American system and realise that they were "slaves in the midst of freedom, waiting patiently, and unconcernedly-indifferently, and stupidly for masters to go and lay claim" on them (p.155). In such an environment, Delany saw "emigration of colored people" (p.159) as one of the options available to them. The question Delany appears to address in the face of the Fugitive Law is what do you choose: re-enslavement or emigration?

Whereas he strongly opposes the African Colonisation Movement, Delany does not completely rule out Africa as a possible destination. Delany attributes his objections to the Society's diabolical designs for AfricanAmericans. Moreover, he finds the geographical position of Liberia discouraging. Delany, as he grappled with realities in America, was later to experiment with an idea of establishing a colony on the Niger under the African Civilisation Society (not to be Confused with the Colonisation Society). This plan, however, fell through before it could be implemented. Some of the members of this society were also members of the African Colonisation Movement. The only added tag was "civilization," one of the major aims of the African Colonisation Society, and that this was supposed to 
come under the umbrella of voluntary emigration not "forced deportation". In addition, Delany explores many other possibilities before settling on South America. Despite his designs on emigration being seemingly contradictory and over-ambitious, Delany, apart from looking at issues of the place of the American Negro in America, also explored other possibilities. Delany pounces on this assertion, arguing that from "our oppressor's own showing, we are $a$ superior race, being endowed with properties fitting us for all parts of the earth, while they are only adapted to certain parts" (p.202). Apart from making a mockery of the designers of the African Colonisation Movement, Delany also reasserts the point that the African can live wherever he wants. Though his emigration policy is the least convincing part of his argument it also sowed the seeds of Pan-Africanism, of looking for strength from the commonality of race, shared history and experience.

\section{CONCLUSION}

For Walker and Delany, the rhetorical strategy was to undermine the Colonisation Movement and highlight the issue of liberty and equality for the African Americans. Walker challenged African-Americans to stop relying on the goodwill of the whiteman to establish their humanity and liberty. Delany, like Walker, showed that African-Americans have the potential to liberate themselves if only they can take the initiative. Generally, both rhetoricians exploit the contradiction in Jefferson's statements to build their arguments. They were all united in dismissing claims that the African-American was "inferior" and that his "native land" was Africa. They both found strength in ironically harping on Jefferson's dictum that "all men are born equal.” By insisting on the potential for the blacks to make it within America, they managed to destroy the basic principle on which the African Colonisation Movement was based. Thus, these rhetoricians exploited the ambivalence embodied by Jefferson's idea to advance their pro-African-American arguments. In other words, Walker's Appeal and Delany's Condition have more in common than scholars have bothered to acknowledge.

\section{REFERENCES}

American Colonization Society. (1832) American Colonization Society and the Colony of Liberia. Boston: Prekins \& Marvin, 1832 reprinted in William Lloyd Garrison. Thoughts on African Colonization. New York: Arno Press, 1968

Blackett, R.J.M. (1986). Beating Against the Barriers. Baton Rouge: Louisiana State University Press

Bizzell, P. (1997). The 4th of July and the 22nd of December: The Function of Cultural Archives in Persuasion, as Shown by Frederick Douglass 
and William Apess. College Composition and Communication, 48:1, pp 44-60

Brown, R. D. (1979) Free Blacks’ Rhetorical Impact on African Colonization: The Emergence of Rhetorical Exigence. Journal of Black Studies 9: 3, pp. 251-265

Delany, R. M. (1852) The Condition, Elevation, Emigration, and Destiny of the Colored People of the United States. New York: Arno Press, 1968

Forbes, E. (1990) African-American Resistance to Colonization. Journal of Black Studies 21: 2, pp. 210-223

Hite, R.W. (1974). Voice of a Fugitive: Henry Bibb and Antebellum Black Separatism.” Journal of Black Studies, 4: 3, pp. 269-284

Jefferson, T. (1904) The Works of Thomas Jefferson, Vol. 4. edited by Paul Leicester Ford. New York: G. P. Putnam’s Sons

Horton, J. O. (1976). Generations of Protest: Black Families and Social Reform in Ante-Bellum Boston. The New England Quarterly 49: 2, pp. 242-256

Katz, W. L. (1968). Introduction. Garrison, William Lloyd. Thought on African Colonization, New York, Arno Press, 1968

Khan, R. M. (1984). The Political Ideology of Martin Delany. Journal of Black Studies 14.4, pp. 415-44

Levine, R. S. (1997). Martin Delany, Frederick Douglass and the Politics of Representative Identity. Chapel Hill, U of North Carolina, pp. 58-98

Mehlinger, L. R. (1916). The Attitude of the Free Negro Toward African Colonization. Journal of Negro History 1: 3, pp. 276-301

Moses, J. W. (1978). The Golden Age of Nationalism. Hamden, Anchor Books

McPherson, J. M. (1965). Abolitionist and Negro Opposition to Colonization during the Civil War. Phylon 26: 4, pp. 391-399

Rosen, B. (1972). Abolition and Colonization, the Years of Conflict-18291834. Phylon 33: 2, pp. 177-192.

Shelby, T. (2003). “Two Concepts of Black Nationalisms: Martin Delany on the Meaning of Black Political Solidarity.” Political Theory 31: 5, pp. 664-692

Staudenraus P.J. (1961). The African Colonization Movement 1816-1865. New York, Columbia University Press

Swift, D.E. (1973). "Black Presbyterian Attacks on Racism.” Journal of Presbyterian History, p.51

Walker, D. (2000) David Walker's Appeal to the Coloured Citizens of the World ed. by Peter P. Hinks, Pennsylvania: The Pennsylvania State University Press, 2000

Wallace, M. (1997). “ ‘Are We Men?’: Price Hall, Martin Delany and the Masculine Ideal in Black Freemasonry, 1775-1865” American Literary History 9:3, pp. 396-424 